\title{
Stomatocyte Count
}

National Cancer Institute

\section{Source}

National Cancer Institute. Stomatocyte Count. NCI Thesaurus. Code C74708.

The determination of the number of stomatocytes present in a sample. 